\title{
Extended Reality for Enhanced Telehealth During and Beyond COVID-19: Viewpoint
}

Triton Ong ${ }^{1}$, PhD; Hattie Wilczewski ${ }^{1}$, BSc; Samantha R Paige ${ }^{1}, \mathrm{PhD}, \mathrm{MPH}, \mathrm{CHES}$; Hiral Soni ${ }^{1}$, PhD, MBA, MSc; Brandon M Welch ${ }^{1,2}, \mathrm{PhD}, \mathrm{MS}$; Brian E Bunnell ${ }^{1,3}, \mathrm{PhD}$

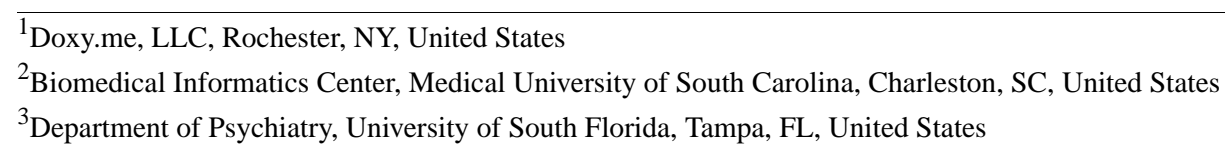

Corresponding Author:

Triton Ong, PhD

Doxy.me, LLC

3445 Winton Place, Suite \#114

Rochester, NY, 14623

United States

Phone: 11844436996

Email: triton.ong@doxy.me

\section{Abstract}

The COVID-19 pandemic caused widespread challenges and revealed vulnerabilities across global health care systems. In response, many health care providers turned to telehealth solutions, which have been widely embraced and are likely to become standard for modern care. Immersive extended reality (XR) technologies have the potential to enhance telehealth with greater acceptability, engagement, and presence. However, numerous technical, logistic, and clinical barriers remain to the incorporation of XR technology into telehealth practice. COVID-19 may accelerate the union of XR and telehealth as researchers explore novel solutions to close social distances. In this viewpoint, we highlight research demonstrations of XR telehealth during the COVID-19 pandemic and discuss future directions to make XR the next evolution of remote health care.

(JMIR Serious Games 2021;9(3):e26520) doi: 10.2196/26520

\section{KEYWORDS}

extended reality; virtual reality; augmented reality; mixed reality; telehealth; telemedicine; COVID-19; telepresence

\section{Introduction}

In-person health care became limited during the COVID-19 pandemic. Social distancing, travel restrictions, and lockdowns forced many to perform and receive health care remotely via telecommunication (ie, telehealth) [1]. Telehealth emerged as a widely effective and accepted solution to support continuity of care throughout the ongoing pandemic [2-4]. Consensus among providers, patients, and policymakers indicates that the shift to telehealth will likely continue even after the pandemic ends [5-7]. To maintain current uptake and support delivery of the best possible care in the future, telehealth needs to supplement and transcend traditional models of in-person care.

As the health care industry adapts to telehealth, aspects of in-person treatment must be optimized for remote care (eg, conversational flow, physical evaluation, therapeutic presence). Some patients report reluctance to self-advocate during typical telehealth sessions because of poor eye contact and audio interference if more than one person speaks at a time [8]. Providers may find it difficult to build rapport and express empathy with patients via telehealth due to limited visibility of body language and the unavailability of physical presence [9]. Both providers and patients can encounter distractions as telehealth is conducted from within their homes [10]. Although telehealth appears set to become the new norm, novel approaches are needed to optimize patient outcomes by restoring critical aspects of in-person health care for remote formats and expanding clinical options to deliver health services at a distance.

Technologies that evoke presence-the perception, feeling, and interaction with simulations as if they were real [11]—can meaningfully impact the practice and outcomes of telehealth. Immersion into fully simulated virtual reality (VR) [12], simulated objects or overlays superimposed onto users' real sight in augmented reality (AR) [13], or direct interaction between simulations and the physical world in mixed reality (MR) [14] each afford new ways to support, extend, and enhance 
health care practice in the shift to remote delivery. These VR, $\mathrm{AR}$, and MR technologies - collectively referred to as extended reality (XR) - have been demonstrated for inpatient and outpatient psychiatric, medical, and rehabilitative applications with equal or greater effectiveness than their non-XR standard treatments [13,15-17]. However, research on XR as an extension of remote health care is comparatively recent and has yet to be synthesized.

The need to explore XR for telehealth has never been greater than in the fallout of COVID-19. Postponement of regular and preventive medical care, the psychological and developmental impacts of the extended pandemic, and escalating reports of provider burnout are harrowing signs on the health care horizon [18-26]. Research on the combination of XR and telehealth embodies recent events, addresses current limitations of conventional telehealth, and paves the path for the health care of tomorrow. We believe that XR telehealth research performed since the onset of COVID-19 will set the tone for research and innovations in the coming years. In this viewpoint, we provide a narrative review of current $\mathrm{XR}$ telehealth research and highlight future directions to address remaining barriers.

\section{XR for Telehealth Before COVID-19}

The potential for reality-altering technologies in remote health care has been heralded since the earliest days of VR. Early VR required complex and costly computing hardware that kept the technology localized, for use by a single individual, and prohibitively expensive until the proliferation of the internet and affordable computing hardware [27,28]. Once the internet became widely available in the mid-1990s, surgical applications of VR and AR expanded to include multiuser supervision by remote experts, and detailed simulations to plan and practice surgical procedures [29-31]. Growing interest in interactive therapy drove MR technologies for at-home telerehabilitation, sometimes using off-the-shelf video game console hardware $[32,33]$. XR gradually matured with consumer-oriented hardware and software packages that led to interdisciplinary developments such as online VR for psychiatric treatments and sophisticated medical training simulations [34,35]. However, costs and technical complexity remained barriers to the wide deployment of XR for telehealth [36].

Trends in home computing and entertainment made user-friendly, robust, and polished XR equipment available for personal ownership in the 2010s, which facilitated the rapid growth in XR telehealth research and development [37]. Since then, XR telehealth has expanded to a wide variety of remote health care applications in AR telesurgery and telesupervision, MR training and simulations, VR telemental health, and telemonitoring of fully remote interventions and specialized medical equipment with VR/AR [13,38,39]. Similar growth occurred in consumer markets with reported use of entertainment VR apps and video games for therapeutic purposes such as mental wellness, identity exploration, healthy aging, and social anxiety [40-42].

Advances in internet infrastructure, computer technology, and portable consumer entertainment gradually decreased costs and increased consumer interest in XR devices. Increasing

commercial availability of these devices and continued innovative research placed XR telehealth on a mainstream trajectory in 2019 [43].

\section{XR for Telehealth During COVID-19}

\section{Resource Constraints and the Rise of Telehealth}

In early 2020, the World Health Organization declared the COVID-19 pandemic and promoted social distancing to limit the spread [44]. Soon after, mass consumption of personal protective equipment (PPE) such as N95 face masks, medical-grade sanitizers, and disposable gloves led to global supply shortages for both health care workers and the general population [45]. The health care industry's primary response to COVID-19 and PPE shortages was a rapid and widespread shift to remote services $[4,46]$. By June 2020, in-person health care visits were down by $30 \%$ while telehealth visits increased by up to $2013 \%$ [47]. This shift was even more pronounced for mental health services, which saw $70 \%$ fewer patients in person while telehealth sessions increased by up to $6558 \%[48,49]$.

XR telehealth was reported to be an effective solution that enhanced safety and reduced PPE consumption in COVID-19 health care settings. Two frontline case studies showed how medical specialists, unable to travel during quarantine, used AR to provide remote consultation and ventilator management for COVID-positive patients [50,51]. Intelligent AR information displays enhanced the workflows of frontline hospital staff to increase clinical efficiency, improve remote team communications, reduce COVID exposure by $51.5 \%$, and decrease PPE consumption by $83 \%$ [52]. VR simulation systems for trauma and emergency medicine offered effective and high-fidelity alternatives to traditional supervision with less need to consume PPE for on-site medical training [53]. XR telehealth alternatives were also demonstrated for patient therapy. A VR group-singing intervention as respiratory therapy for spinal cord injury was found to be feasible, acceptable, enjoyable, and reported as less socially inhibited than the in-person prospects of the same intervention [54]. General population users in another feasibility study favored telemental health in VR over the standard webcam format [55]. Multiuser VR in analog telehealth conditions was found to be an ideal environment to conduct evidence-based cognitive behavioral therapy $(\mathrm{CBT})$ in a space that felt immersive, expressive, private, anonymous, and free from judgment [56]. Overall, this published research shows that XR technologies complemented telehealth solutions to support frontline health care workers and maintain social distancing for critical evidence-based treatments during COVID-19.

\section{Access to Medical and Mental Health Care}

In addition to social distancing, local and state governments imposed travel restrictions to limit the transmission of COVID-19 and reduce strain on health care systems [57]. However, these restrictions entailed collateral costs to the public's health. Reduced public transportation disproportionately impacted lower-income and ethnic groups in urban areas, and further destabilized access to health care in rural regions with few local specialists [58-60]. Extended pandemic conditions also increased the global risk of psychological distress, impacted 
people's daily habits and life plans, and subjected vulnerable populations to prolonged social isolation $[57,61]$.

Barriers to health care access intensified during the pandemic and XR telehealth emerged as a responsive option. XR telehealth had a particularly significant impact to increase the immediacy of care and access among medically and geographically isolated populations who required continual rehabilitation services $[62,63]$. In addition to providing immersive and accessible care, XR telehealth connected people in virtual spaces to combat social isolation and maintain health-promoting social relationships over distances [64]. For example, location-based AR video games provided a protective effect for social, physical, and mental health during the pandemic [65-69]. Experts also promoted XR telehealth developments as a potential solution to address the downstream developmental impacts of the prolonged pandemic upon children and adolescents who eagerly take to new technologies [25,70].

\section{Burnout and Contagion Exposure Among Health Care Workers}

The psychological distress of COVID-19 was particularly burdensome for health care workers. Sudden increases in workload, overcrowding, medical supply shortages, exposure to the virus, and the suffering of patients led to extreme physical and emotional strain upon frontline and hospital staff [22,71-73]. Health care workers were seven times more likely to exhibit severe COVID-19 symptoms than other workers due to their frequent and extreme exposure to contagion environments [74]. It is estimated that more than 3500 US frontline health care workers have died from COVID-19 contracted during their health care service [75]. Burnout among health care workers proved to be another contagion that spread within hospital wards with cascading staff turnover, compassion fatigue, and secondary traumatic stress [76,77]. Experts anticipate severe downstream impacts upon health care workers, and urge for evidence-based therapeutic interventions responsive to the impacts of COVID-19 and for methods to reduce health care workers' exposure to the virus [78-81].

CBT for mindfulness is known to alleviate burnout and improve overall mental wellness among health care workers [71,82-84]. $\mathrm{XR}$ virtual visits have emerged as a promising technology for stress reduction using CBT and other evidence-based telemental health approaches $[85,86]$. With the advent of telehealth, VR and AR for COVID-related stress and trauma therapies have been promoted for distribution among frontline health care workers $[51,87,88]$. Although these studies are ongoing, VR telehealth for posttraumatic stress among survivors of COVID-19 has shown promising effects [89,90], and it is reasonable to expect these effects to generalize to providers from these same environments and traumatic experiences [91]. In addition to targeting burnout among health care workers, XR has been used to innovate health care workflows with remote, intelligent, and burnout-reducing solutions. A preliminary application of AR telesurgical consultations allowed remote specialists to provide real-time expertise for COVID-positive patients without travel or exposure risks, paving a way for large-scale future implementation [50]. Interconnected AR systems improved infection control, increased access to specialist remote supervision, reduced time spent in contagion environments, and enhanced clinical workflows in frontline health care environments [51,52].

\section{Economic and Professional Pressures on Health Care Providers}

The accumulated effects of social distancing, chronic resource shortages, travel restrictions, hospital surges, and pandemic stress created instability for current and future health care providers. By August 2020, more than 16,000 private practices had permanently closed with $41 \%$ of their peers facing the same fate with unsustainable loss of staff, patients, and income [20]. The subsequent low viability of for-profit clinics exacerbated concerns with reduced health care support [92]. This new fragility in health care networks was particularly straining for already underserved rural regions and ethnic populations [93,94]. Prolonged pandemic conditions further inhibited traditional pathways to hands-on health care experience and clinical supervision, which delayed professional development of the next generation of health care providers [95-97]. Governments, hospitals, and health care providers rallied to support public health during COVID-19, but extended pandemic conditions created a clear need for remote health solutions to sustain health care practice, improve access to health care, and provide quality health care education.

Many aspects of health care and education were ready for XR and telehealth before the pandemic but remained underutilized due to equipment costs, unresponsive legislation, and limited health insurance coverage $[98,99]$. COVID-19 produced the conditions necessary to accelerate change, and now provides ample opportunity for those who embrace telehealth and complementary technologies. XR telehealth allowed providers to deliver services into patients' own homes and naturalistic environments, which has long been a limitation of traditional clinical treatment [100]. Low-cost, off-the-shelf hardware and royalty-free software for therapy and rehabilitation made XR telehealth an economically feasible solution [101,102]. XR telehealth training and education also rose in response to COVID-19. The realistic, interactive capabilities of XR were broadly promoted as a solution to reach and educate patients and trainees over distances [103]. Simulations in VR and AR were common, safe, and repeatable alternatives to risky on-site in-person medical student training [104-106]. A cohort of medical-surgical students set to graduate during COVID-19 rated VR training as realistic for $77 \%$ of clinical assessments, $81 \%$ of treatment options, and $94 \%$ of diagnostics. After exposure to the virtual training, $84 \%$ of the cohort reported interest in the future use of VR for medical training and $90 \%$ overall satisfaction with virtual learning [107]. The rise of telehealth provided options for health care providers to sustain their practice when in-person visits became unfeasible. As part of telehealth, XR also proved to be a critical solution to provide health services and education amid pandemic conditions. 


\section{XR Telehealth After COVID-19}

\section{General Prospects}

The impact of COVID-19 on the health care industry was sudden, severe, and broad. Longitudinal data are necessary to evaluate XR telehealth as an alternative to traditional in-person treatment and training. Nevertheless, XR telehealth served as a critical solution to the emergent conditions of COVID-19, maintenance of health care systems, and preparation of future providers. Telehealth is likely to become a staple of health care practice, as the majority of patients and more than $90 \%$ of providers intend to continue remote care beyond the resolution of COVID-19 [108-113]. Telehealth on its own is broadly effective and accepted but still leaves some patients and providers dissatisfied with their interactions with providers, specifically in their ability to feel present and build therapeutic relationships [114-116]. This lack of communicative nuance creates a vagueness in non-XR telehealth interactions that can be interpreted as awkward or even malicious [117]. Continued research and development of XR for telehealth can address some of these barriers to enhance therapeutic relationships, expand clinician capacity, and empower patients toward optimal health outcomes.

\section{XR Can Facilitate Telepresence to Strengthen Teletherapeutic Relationships}

Therapeutic alliance is one of the best predictors of treatment success and health outcomes [118-120]. Therapeutic alliance is broadly defined by the relationship between the provider and patient, fostered through mutual agreement of clinical goals and the strategies to achieve those goals [121]. Non-XR telehealth is effective, accepted, and sustainable, but can make it difficult to replicate the communicative nuances and rapport building of in-person health care $[122,123]$. Health care providers who seem rigid, distant, or distracted (ie, typical attributes of non-XR telehealth [124,125]) produce poorer therapeutic alliances [126], which lead to higher chances of dropout, dissatisfaction, and negative health outcomes [127-129]. As a result, a small but important minority of providers believe that their patients do not enjoy telehealth as much as in-person care $[116,130]$.

Preliminary evidence shows that XR can enhance remote interactions to strengthen therapist-patient relationships. Patients who received interactive CBT using VR avatars reported feeling less judged by their physical appearance, that the VR space was somewhere they could be honest and private with their therapist, and that the interaction felt more casual than an in-person clinic visit [56]. Likewise, physicians reported building rapid trust with their patients while jointly viewing patient body scans in VR and AR [131]. VR has also been promoted over non-VR alternatives for benefits such as more comfortable treatment, higher engagement, greater satisfaction, more consistent practice, greater skill transfer, and facilitation of nonverbal communication that improves therapist-client contact [132].

XR facilitates presence, when one perceives that the virtual environment is real [11]; embodiment, when one perceives a virtual body as one's own real body [16]; and telepresence, when one perceives that they are inhabiting another place with virtual others [133]. Each of these aspects can aid in the establishment, improvement, and maintenance of therapeutic alliances in telehealth. Miloff and colleagues [134] developed an automated AR hologram embedded in VR exposure therapy and demonstrated that therapeutic alliance measures generalized to the virtual therapist. Although patients reported positive perceptions of this audio-only VR therapist, visually and behaviorally realistic VR therapists have been shown to evoke greater perceived presence [135]. Realistic XR avatars and XR interactions tend to evoke stronger physical and emotional closeness and greater confidence in the credibility of the therapist [135-137], which are key factors that influence an alliance with a virtual health care provider. However, XR telehealth is a nascent field, and more research is needed to understand how the two technologies interact to cultivate therapeutic alliances and impact health outcomes.

\section{XR With Telehealth Can Expand the Reach of Clinicians and Researchers}

XR technologies were used frequently for health care education and training prior to COVID-19 [138-140], and this practice is expected to become increasingly common as traditional on-site medical education remains limited under the pandemic [86,104]. Simulation training in XR provides highly realistic experiences that deeply immerse learners in clinically realistic scenarios to facilitate skill acquisition and skill transfer for real application [141]. XR simulations can also provide repeatable exposure to important but improbable clinic scenarios, to prepare for states of emergency, and to access otherwise impossible views of medical procedure [103,142]. Remote XR simulations were used to facilitate skill development, prevent contagion spread, and rapidly disseminate COVID-relevant medical education during the pandemic [52,104,105]. Although the relationship between XR simulation training and clinical outcomes remains unclear [138,143-145], further exploration of remote XR training can help health care workers acquire, develop, and maintain cutting-edge skills with limited access to facilities or clinical populations. XR simulations stand to benefit from technologies to enhance realism and transfer of skills such as remote supervision, haptic feedback, anatomical replicas responsive to $\mathrm{MR}$, and artificial intelligence to provide the most flexible and clinically beneficial education of future health care providers [146].

Health care is complex, fluctuating, and high-stakes work that often necessitates coordination of schedules, tasks, and information between multiple providers and teams. Unfortunately, hospitals are notoriously inefficient and error-prone due to a historic lack of human factors considerations in workflows, communications, equipment, user interfaces, and physical environments [147-150]. XR can play an important role in connected collaborative health care. Telesurgery with $\mathrm{AR}$ is a prominent example of how the marriage of XR and telehealth can improve health care work environments with surgeons receiving notes from expert consultants directly on their real-time view of the patient, seeing a proctor's hands directing incisions, and delivering the expertise of medical specialists to regions with few or no local specialists $[13,14,50,151]$. The benefits of XR telesurgery have recently been demonstrated in nonsurgical medical teams for live 
distanced collaboration for inpatient unit care and coordination $[51,152,153]$. XR technologies enable immersive learning environments and pervasive sensor-display interfaces in the field. Telehealth enables real-time remote specialist consultation and expert supervision. The combination of XR and telehealth represents a system of potential force multipliers that can support, improve, and extend the capabilities of health care practitioners.

XR telehealth has increased patient access to health care, but this relationship has rich bidirectional potential to explore; clinicians and researchers can use XR telehealth to gain better access to patients and participants. Persky [154] described how controlled programmatic XR experiences could merge with remote clinical trials to minimize researcher and participant travel burdens; streamline and automate data collection; and critically improve engagement, retention, and procedural integrity. The recent popularity of consumer XR entertainment devices such as Facebook Oculus Quest 2, Sony PlayStation VR, and smartphone-based Google Cardboard can function as recruitment, enrollment, and data collection solutions with access to participants in their naturalistic settings. The use of fictionalized XR avatars to represent researcher and participant bodies can provide complete control over social manipulations and single- and double-blind study logistics [155]. Complicated data displays, technical instructions, and study processes such as informed consent are also easy for participants and researchers to visualize and interactively explore together in XR [156-158]. It will be critical to study XR for telehealth as a solution to extend historically localized research practices with mobility deployment to the general public and outreach for remote, underserved populations [159].

\section{XR Can Empower Patients to Seek Health Care and Improve Outcomes}

Patients are empowered when they are treated as active collaborators in understanding and making decisions about their health care, rather than as passive subjects merely compliant with "doctors' orders" [160]. Telehealth has already improved patients' access to health care by removing geographical barriers (eg, travel costs and arrangements); however, remaining social and behavioral barriers to patient empowerment may be addressed with humanizing and engaging XR technologies.

There are widespread cultural stigmas that inhibit health-seeking behavior [161,162]. For example, men tend to avoid medical and mental health care to the point of early death and preventable decline in quality of life [163-165]. Other stigmas of diagnosis, gender, sexuality, ethnicity, body image, criminal history, and others similarly compromise health care utilization and outcomes [166-170]. Telehealth provides a beneficial distance that can make patients with stigmatized conditions feel confident and comfortable seeking services from their own homes [171-173]. XR can further enhance telehealth to include temporary, therapeutic distance from stigmatized bodies or identities. Avatars are 3D computer-generated models used in virtual environments to represent agents (eg, patients, providers, computer-controlled characters) [174]. The simulated nature of XR avatars makes them uniquely flexible for personalized health care approaches and interventions. One's avatar can resemble their physical likeness in XR therapies faithful to what they would be like during an in-person health care visit [142]. Alternatively, patients may build a fictionalized avatar to provide a more comfortable degree of anonymity, extend embodiment-oriented therapies, and as a clinical enhancement for telehealth providers' web-side manner [175,176]. Matsangidou and colleagues [56] recently demonstrated the many benefits of fictionalized avatars in VR treatment for both therapists and patients. Therapists tasked patients to build their own avatars, which provided useful clinical insights as to how the patient viewed themselves (ie, avatar appearance compared to real body). Patients attributed a wide variety of subjective benefits to the use of VR avatars, the most important of which were corroborated by therapists who noticed that avatars occasioned remarkable patient openness and trust. Interestingly, the therapists were also depicted with VR avatars in the form of simplistic cubes that were reported to enhance patients' willingness to discuss difficult topics and engage in other mental health exercises. Telehealth allows patients to access health care with no need to travel, and XR can further enable access to care with no need for concern they will be judged. It will be important to explore avatars in XR telehealth as a solution for stigmas of visible medical conditions (eg, skin disease and burns) $[177,178]$, criminal history or potential (eg, prevention of offense related to sexual preference) $[179,180]$, and provide unprecedented opportunities for mental health and wellness [86,181,182].

The presence of and embodiment facilitated by avatars in responsive XR environments can result in simulated experiences that feel more real than physical reality (ie, hyperpresence) [183]. This hyperpresence may have tremendous clinical potential for remote health care. For example, patient motivation tends to be low for at-home rehabilitation due to the gap between unpleasant exercise and long-term health outcomes [184-186]. $\mathrm{XR}$ can boost the salience of physical rehabilitation with fictional but proactive feedback, similar to those in modern entertainment video games. Exaggerated body tracking in XR showed participants' virtual bodies as stretching further and running faster than their real bodies, which significantly improved performance, enjoyment, and motivation for unsupervised rehabilitation-oriented exercises [187,188]. Hyperpresence in XR can also enable treatment contexts that in-person care and telehealth cannot. Traditional mental health treatments for internal stimuli (eg, emotional states or auditory hallucinations) rely on guided imagination that can alternatively be visualized and engaged with directly in XR [189,190]. Further, counterfactual hyperpresence can make health care more approachable for the shy or therapies that can be socially awkward. Group singing is an effective and cost-efficient intervention to promote respiratory health, but participants report lack of confidence when singing in front of others [191]. The same group-singing intervention in remote VR made participants feel socially uninhibited owing to their manifestation as anonymous and nonhuman VR avatars [54]. Hyperpresence is an emerging concept that merits investigation as a potential path for XR to enhance telehealth patient engagement, retention, and comfort. XR is currently used to alter patients' sense of where they are and what they are doing but can also enhance patients' sense of who they are in the future of telehealth [192]. 


\section{Remaining Barriers and Steps Forward}

Telehealth revolutionized health care to meet patient needs at a distance. Although the majority of telehealth adoption was due to the pandemic, it is clear that telehealth will continue to expand beyond the resolution of COVID-19. We believe that $\mathrm{XR}$ is the next evolution for remote care built upon decades of foundational research and innovative demonstrations published in response to COVID-19. Toward that future, however, the barriers to XR are broadly similar to those of telehealth. Both technologies involve costly investments in equipment and training, can be abandoned after investment because of poor usability, and rely on broadband internet access that limits access on the basis of socioeconomic status and geographic location [151,193-195]. To realize the telepresent and empathetic future of XR telehealth, key barriers to mainstream adoption of both technologies must be addressed.

XR technologies involve complex electronic sensors, displays, and networks, which make costs a constant prohibitive factor. In 2000, a clinically sufficient VR headset with necessary computers and proprietary software could cost approximately US \$17,000 (adjusted for 2021 inflation) [34]. However, high-end VR setups can be purchased today for use in one's own home for about US $\$ 3000$ total with a growing variety of free-to-use and open-source software [196]. Low-end XR (eg, Google Cardboard VR, Holokit AR) costs as little as US $\$ 15-\$ 50$, involves the use of smartphones many people already own, and has been applied with clinically significant treatment success $[102,197]$. Costs are anticipated to continue decreasing as consumer XR hardware becomes more established [198]. Concerns over costs can be further addressed with formal cost-benefit analyses of comparative treatment costs and impacts on quality of life.

Commercially produced XR hardware removes many barriers for health care providers interested in the technology, but this reliance on proprietary devices and software can be a double-edged sword for telehealth. Privacy is an ongoing concern with increasingly interconnected health care technologies [199]. This issue is particularly tricky with XR, as few devices exist on consumer markets that are compliant with regulatory health policies and the constantly evolving ways people use XR [40,200,201]. Although XR telehealth can feel private, the reality is that many $\mathrm{XR}$ devices and applications needlessly collect identifiable information and share user data with third parties. Certain XR devices such as Oculus Quest 2 are inoperable without data logging, and the manufacturer explicitly discourages its use with protected health information [202]. The recent rapid uptake of telehealth and XR continues to highlight the need for privacy and policy focused on health care end users [203]. Health care researchers, clinicians, consumers, and XR developers will need to organize and openly communicate to promote transparent and responsive privacy measures.

As a relatively new area of research, XR telehealth has a growing number of ethical concerns to address. First, the contexts in which XR telehealth are or are not appropriate have not been well established. XR telehealth may not benefit all health conditions or contexts equally. Treatment of high-risk conditions (eg, suicidality) still necessitates in-person responsiveness, while XR remains inaccessible to some (eg, those with chronic neurological conditions) or is unlikely to help others (eg, those with acute delirium). Second, practice competency is unclear with emerging telehealth and XR technologies. The broad foundational principles of competency are expected to be maintained as the public settles into widespread utilization of telehealth [204,205]. However, few telehealth practitioners are also experienced in software and hardware development. This current reality leaves most decisions about XR telehealth features and functions out of the hands of health care providers, making interdisciplinary collaborations a vital need into the future [206]. Third, the unique uses of XR for telehealth carry equal potential for misuse. Immersion, presence, copresence, and embodiment can facilitate remote health care, but it is not yet known how to best utilize these components or when one component should be emphasized over others. Modification of experiential states needs to be transparent and responsible in proportion to the potential risks [207]. Organizations for health care research and practice will need to establish and discuss ethical guidelines for XR telehealth. This is particularly important in light of reports that some are using nonmedical technology resources (eg, apps, games, websites) in lieu of qualified health care and the growing availability of self-help resources with little or no medical oversight [208,209].

In current and coming years, XR content offerings may be the greatest barrier for deployment via telehealth. There are currently about 60 million regular VR users and 91 million regular users of AR in the United States [210]. Major technology companies aim to make XR ubiquitous in the near future, which may make telehealth a more appealing use case for XR [211]. Although there is a growing variety of commercial XR telehealth options, the vast majority of XR consumption is for entertainment and industrial application [212]. XR for telemental health is promising, but uptake has been slow due to lack of usability or easy integration into existing clinical workflows $[14,195,213]$. It will be vital for researchers, clinicians, and developers to collaboratively assure that telehealth is a priority market in the design of XR hardware and software [214]. Furthermore, there are currently few sources of reputable, evidence-based, comprehensive information for telehealth providers to learn about and make treatment decisions with XR. Scholarly, clinical, and patient advocacy organizations should formally curate XR hardware and software to help navigate emerging treatment options for telehealth providers and patients.

The research literature on XR for telehealth is new, vast, and accelerating. The wide variety of XR hardware and software, study designs and populations, metrics and outcome variables, and vocabularies can be difficult to navigate and synthesize. The parameters of what constitutes VR, AR, and MR are still being explored, leaving overlap and obscurity in terms for practice and literature searches [215,216]. A consistent finding in XR narrative, systematic, and meta-analytic reviews is the variability in approaches that prevent formal comparison between studies [14,143,217]. Toward that end, Birckhead and colleagues [218] have provided recommendations to guide 
progressive and programmatic lines of XR research. Other good practices in this field of research include pretraining to orient participants to XR and minimize error, repeated exposure to detect and control for novelty confounds, and on-demand technical support during XR studies [54,219,220]. Failures with $\mathrm{XR}$ telehealth are equally important to publish as successes to accumulate details relevant to application and sustainability. Consistency of language, replicability, long-term effectiveness, and best practices for implementing XR telehealth must be disseminated to establish a comprehensive and conceptually systematic literature.

\section{Conclusion}

Studies published during the COVID-19 pandemic showed that XR for telehealth helped health care providers stay safe during treatment of COVID-19 patients, improved the way health care was delivered to patients remotely, helped sustain a healthy frontline health care workforce, and supported the professional development of current and future providers. Toward the future of telehealth, we argue that XR can enhance interactive nuances and treatment options for telehealth patients, function as a force multiplier for health researchers and clinicians, and provide new options for at-risk patient populations. Cost, privacy, ethical practice, actionable practice guidelines, and improvements to research approaches must be addressed to fully realize the potential benefits of XR for telehealth. Despite these barriers, XR technologies have unique potential to enhance, extend, and expand the future of telehealth in and beyond the COVID-19 pandemic.

\section{Conflicts of Interest}

BW is a shareholder and all other authors are employees of Doxy.me, LLC, a commercial telemedicine company. The authors declare no other conflicts of interest.

\section{References}

1. Ohannessian R, Duong TA, Odone A. Global telemedicine implementation and integration within health systems to fight the COVID-19 pandemic: a call to action. JMIR Public Health Surveill 2020 Apr 02;6(2):e18810 [FREE Full text] [doi: 10.2196/18810] [Medline: 32238336]

2. Abdel-Wahab M, Rosenblatt E, Prajogi B, Zubizarretta E, Mikhail M. Opportunities in telemedicine, lessons learned after COVID-19 and the way into the future. Int J Radiat Oncol Biol Phys 2020 Oct 01;108(2):438-443 [FREE Full text] [doi: 10.1016/j.ijrobp.2020.07.006] [Medline: 32890528]

3. Sosnowski R, Kamecki H, Joniau S, Walz J, Klaassen Z, Palou J. Introduction of telemedicine during the COVID-19 pandemic: a challenge for now, an opportunity for the future. Eur Urol 2020 Dec;78(6):820-821 [FREE Full text] [doi: 10.1016/j.eururo.2020.07.007] [Medline: 32703638]

4. Garattini L, Badinella Martini M, Zanetti M. More room for telemedicine after COVID-19: lessons for primary care? Eur J Health Econ 2021 Mar;22(2):183-186 [FREE Full text] [doi: 10.1007/s10198-020-01248-y] [Medline: 33231825]

5. Khan N, Jones D, Grice A, Alderson S, Bradley S, Carder P, et al. A brave new world: the new normal for general practice after the COVID-19 pandemic. BJGP Open 2020 Aug;4(3):bjgpopen20X101103 [FREE Full text] [doi:

10.3399/bjgpopen20X101103] [Medline: 32487520]

6. Nguyen M, Waller M, Pandya A, Portnoy J. A review of patient and provider satisfaction with telemedicine. Curr Allergy Asthma Rep 2020 Sep 22;20(11):72 [FREE Full text] [doi: 10.1007/s11882-020-00969-7] [Medline: $\underline{32959158]}$

7. Phend C. Permanent telehealth expansion gains bipartisan support. MedPage Today. 2021 Mar 03. URL: https://www. medpagetoday.com/practicemanagement/telehealth/91461 [accessed 2021-04-19]

8. Gordon HS, Solanki P, Bokhour BG, Gopal RK. "I'm not feeling like I'm part of the conversation" Patients' perspectives on communicating in clinical video telehealth visits. J Gen Intern Med 2020 Jun;35(6):1751-1758 [FREE Full text] [doi: 10.1007/s11606-020-05673-w] [Medline: 32016705]

9. Békés V, Aafjes-van Doorn K. Psychotherapists' attitudes toward online therapy during the COVID-19 pandemic. J Psychother Integr 2020 Jun;30(2):238-247. [doi: 10.1037/int0000214]

10. Almathami HKY, Win KT, Vlahu-Gjorgievska E. Barriers and facilitators that influence telemedicine-based, real-time, online consultation at patients' homes: systematic literature review. J Med Internet Res 2020 Feb 20;22(2):e16407 [FREE Full text] [doi: 10.2196/16407] [Medline: 32130131]

11. Sanchez-Vives MV, Slater M. From presence to consciousness through virtual reality. Nat Rev Neurosci 2005 Apr;6(4):332-339. [doi: 10.1038/nrn1651] [Medline: 15803164]

12. Jerdan SW, Grindle M, van Woerden HC, Kamel Boulos MN. Head-mounted virtual reality and mental health: critical review of current research. JMIR Serious Games 2018 Jul 06;6(3):e14 [FREE Full text] [doi: 10.2196/games.9226] [Medline: 29980500]

13. Eckert M, Volmerg JS, Friedrich CM. Augmented reality in medicine: systematic and bibliographic review. JMIR Mhealth Uhealth 2019 Apr 26;7(4):e10967 [FREE Full text] [doi: 10.2196/10967] [Medline: 31025950]

14. Gerup J, Soerensen CB, Dieckmann P. Augmented reality and mixed reality for healthcare education beyond surgery: an integrative review. Int J Med Educ 2020 Jan 18;11:1-18 [FREE Full text] [doi: 10.5116/ijme.5e01.eb1a] [Medline: 31955150 ] 
15. Maples-Keller JL, Bunnell BE, Kim S, Rothbaum BO. The use of virtual reality technology in the treatment of anxiety and other psychiatric disorders. Harv Rev Psychiatry 2017;25(3):103-113 [FREE Full text] [doi: 10.1097/HRP.0000000000000138] [Medline: 28475502]

16. Riva G, Wiederhold BK, Mantovani F. Neuroscience of virtual reality: from virtual exposure to embodied medicine. Cyberpsychol Behav Soc Netw 2019 Jan;22(1):82-96 [FREE Full text] [doi: 10.1089/cyber.2017.29099.gri] [Medline: 30183347]

17. Beidel DC, Frueh BC, Neer SM, Bowers CA, Trachik B, Uhde TW, et al. Trauma management therapy with virtual-reality augmented exposure therapy for combat-related PTSD: A randomized controlled trial. J Anxiety Disord 2019 Jan;61:64-74. [doi: 10.1016/j.janxdis.2017.08.005] [Medline: 28865911]

18. Lyons D, Frampton M, Naqvi S, Donohoe D, Adams G, Glynn K. Fallout from the COVID-19 pandemic - should we prepare for a tsunami of post viral depression? Ir J Psychol Med 2020 Dec;37(4):295-300 [FREE Full text] [doi: 10.1017/ipm.2020.40] [Medline: $\underline{32408926}$ ]

19. Shah SGS, Nogueras D, van Woerden HC, Kiparoglou V. The COVID-19 pandemic: a pandemic of lockdown loneliness and the role of digital technology. J Med Internet Res 2020 Nov 05;22(11):e22287 [FREE Full text] [doi: 10.2196/22287] [Medline: $\underline{33108313}$ ]

20. The Physicians Foundation. Part three of the 2020 Survey of America's Physicians: COVID-19's impact on the wellbeing of physicians. Merritt Hawkins. 2020 Oct 26. URL: https://www.merritthawkins.com/trends-and-insights/article/surveys/ part-three-of-the-2020-survey-of-americas-physicians-covid-19s-impact-on-the-wellbeing-of-physicians/ [accessed 2021-04-19]

21. Vatansever D, Wang S, Sahakian BJ. Covid-19 and promising solutions to combat symptoms of stress, anxiety and depression. Neuropsychopharmacology 2021 Jan;46(1):217-218 [FREE Full text] [doi: 10.1038/s41386-020-00791-9] [Medline: 32792683]

22. Azoulay E, De Waele J, Ferrer R, Staudinger T, Borkowska M, Povoa P, ESICM. Symptoms of burnout in intensive care unit specialists facing the COVID-19 outbreak. Ann Intensive Care 2020 Aug 08;10(1):110 [FREE Full text] [doi: 10.1186/s13613-020-00722-3] [Medline: 32770449]

23. Gunnell D, Appleby L, Arensman E, Hawton K, John A, Kapur N, COVID-19 Suicide Prevention Research Collaboration. Suicide risk and prevention during the COVID-19 pandemic. Lancet Psychiatry 2020 Jun;7(6):468-471 [FREE Full text] [doi: 10.1016/S2215-0366(20)30171-1] [Medline: 32330430]

24. Lippi G, Henry BM, Sanchis-Gomar F. Physical inactivity and cardiovascular disease at the time of coronavirus disease 2019 (COVID-19). Eur J Prev Cardiol 2020 Jun;27(9):906-908 [FREE Full text] [doi: 10.1177/2047487320916823] [Medline: 32270698]

25. Ye J. Pediatric mental and behavioral health in the period of quarantine and social distancing with COVID-19. JMIR Pediatr Parent 2020 Jul 28;3(2):e19867 [FREE Full text] [doi: 10.2196/19867] [Medline: 32634105]

26. Rauschenberg C, Schick A, Hirjak D, Seidler A, Paetzold I, Apfelbacher C, et al. Evidence synthesis of digital interventions to mitigate the negative impact of the COVID-19 pandemic on public mental health: rapid meta-review. J Med Internet Res 2021 Mar 10;23(3):e23365 [FREE Full text] [doi: 10.2196/23365] [Medline: 33606657]

27. Blanchard C, Burgess S, Harvill Y, Lanier J, Lasko A, Oberman M, et al. Reality built for two: a virtual reality tool. USA: Association for Computing Machinery; 1990 Presented at: Symposium on Interactive 3D Graphics; 1990; Snowbird, UT. [doi: $10.1145 / 91385.91409$ ]

28. Lanier J, Biocca F. An insider's view of the future of virtual reality. J Commun Internet 1992;42(4):150-172. [doi: 10.1111/j.1460-2466.1992.tb00816.x]

29. Satava RM. Virtual reality, telesurgery, and the new world order of medicine. J Image Guid Surg 1995;1(1):12-16. [doi: 10.1002/(SICI)1522-712X(1995)1:1<12::AID-IGS3>3.0.CO;2-P] [Medline: 9079422]

30. Satava RM, Jones SB. Virtual reality and telemedicine: exploring advanced concepts. Telemed J 1996;2(3):195-200. [doi: 10.1089/tmj.1.1996.2.195] [Medline: 10165542]

31. Blackwell M, Morgan F, DiGioia AM. Augmented reality and its future in orthopaedics. Clin Orthop Relat Res 1998 Sep(354):111-122. [doi: 10.1097/00003086-199809000-00014] [Medline: 9755770]

32. Ines D, Abdelkader G. Mixed reality serious games: The therapist perspective. 2011 Presented at: IEEE 1st International Conference on Serious Games and Applications for Health (SeGAH); November 16-18, 2011; Braga, Portugal p. 1-10. [doi: 10.1109/segah.2011.6165462]

33. Weibel N. New frontiers for pervasive telemedicine: from data science in the wild to HoloPresence. USA: Association for Computing Machinery; 2017 Presented at: 11th EAI International Conference on Pervasive Computing Technologies for Healthcare; May 23-26, 2017; Barcelona, Spain p. 276-281. [doi: 10.1145/3154862.3154912]

34. Riva G, Gamberini L. Virtual reality in telemedicine. Telemed J E Health 2000;6(3):327-340. [doi: 10.1089/153056200750040183] [Medline: 11110636]

35. Mantovani F, Castelnuovo G, Gaggioli A, Riva G. Virtual reality training for health-care professionals. Cyberpsychol Behav 2003 Aug;6(4):389-395. [doi: 10.1089/109493103322278772] [Medline: 14511451]

36. Rizzo AA, Strickland D, Bouchard S. The challenge of using virtual reality in telerehabilitation. Telemed J E Health 2004;10(2):184-195. [doi: 10.1089/tmj.2004.10.184] [Medline: 15319048 ] 
37. Rizzo AS, Koenig ST. Is clinical virtual reality ready for primetime? Neuropsychology 2017 Nov;31(8):877-899. [doi: 10.1037/neu0000405] [Medline: 29376669]

38. Mishkind MC, Norr AM, Katz AC, Reger GM. Review of virtual reality treatment in psychiatry: evidence versus current diffusion and use. Curr Psychiatry Rep 2017 Sep 18;19(11):80. [doi: 10.1007/s11920-017-0836-0] [Medline: 28920179]

39. Hu H, Feng X, Shao Z, Xie M, Xu S, Wu X, et al. Application and prospect of mixed reality technology in medical field. Curr Med Sci 2019 Feb;39(1):1-6. [doi: 10.1007/s11596-019-1992-8] [Medline: 30868484]

40. Maloney D, Zamanifard S, Freeman G. Anonymity vs. familiarity: self-disclosure and privacy in social virtual reality. USA: Association for Computing Machinery; 2020 Presented at: 26th ACM Symposium on Virtual Reality Software and Technology; November 1-4, 2020; virtual p. 1-9. [doi: 10.1145/3385956.3418967]

41. Freeman G, Zamanifard S, Maloney D, Adkins A. My body, my avatar: how people perceive their avatars in social virtual reality. USA: Association for Computing Machinery; 2020 Presented at: 2020 CHI Conference on Human Factors in Computing Systems; 2020; virtual p. 1-8. [doi: 10.1145/3334480.3382923]

42. Shao D, Lee I. Acceptance and influencing factors of social virtual reality in the urban elderly. Sustainability 2020 Nov 10;12(22):9345. [doi: 10.3390/su12229345]

43. Wiederhold BK, Riva G. Virtual reality therapy: emerging topics and future challenges. Cyberpsychol Behav Soc Netw 2019 Jan;22(1):3-6. [doi: 10.1089/cyber.2018.29136.bkw] [Medline: 30649958]

44. Prin M, Bartels K. Social distancing: implications for the operating room in the face of COVID-19. Can J Anaesth 2020 Jul;67(7):789-797 [FREE Full text] [doi: 10.1007/s12630-020-01651-2] [Medline: 32291632]

45. Dargaville T, Spann K, Celina M. Opinion to address the personal protective equipment shortage in the global community during the COVID-19 outbreak. Polym Degrad Stab 2020 Jun;176:109162 [FREE Full text] [doi: 10.1016/j.polymdegradstab.2020.109162] [Medline: 32292217]

46. Haque SN. Telehealth beyond COVID-19. Psychiatr Serv 2021 Jan 01;72(1):100-103. [doi: 10.1176/appi.ps.202000368] [Medline: $\underline{32811284]}$

47. Patel SY, Mehrotra A, Huskamp HA, Uscher-Pines L, Ganguli I, Barnett ML. Trends in outpatient care delivery and telemedicine during the COVID-19 pandemic in the US. JAMA Intern Med 2021 Mar 01;181(3):388-391. [doi: 10.1001/jamainternmed.2020.5928] [Medline: 33196765]

48. Humer E, Pieh C, Kuska M, Barke A, Doering BK, Gossmann K, et al. Provision of psychotherapy during the COVID-19 pandemic among Czech, German and Slovak psychotherapists. Int J Environ Res Public Health 2020 Jul 04;17(13):4811 [FREE Full text] [doi: 10.3390/ijerph17134811] [Medline: 32635422]

49. Reilly SE, Zane KL, McCuddy WT, Soulliard ZA, Scarisbrick DM, Miller LE, et al. Mental health practitioners' immediate practical response during the COVID-19 pandemic: observational questionnaire study. JMIR Ment Health 2020 Oct 01;7(9):e21237 [FREE Full text] [doi: 10.2196/21237] [Medline: 32931440]

50. AlMazeedi SM, AlHasan AJMS, AlSherif OM, Hachach-Haram N, Al-Youha SA, Al-Sabah SK. Employing augmented reality telesurgery for COVID-19 positive surgical patients. Br J Surg 2020 Sep;107(10):e386-e387 [FREE Full text] [doi: 10.1002/bjs.11827] [Medline: 32700761]

51. Liu S, Xie M, Ye Z. Combating COVID-19-how can AR telemedicine help doctors more effectively implement clinical work. J Med Syst 2020 Jul 20;44(9):141 [FREE Full text] [doi: 10.1007/s10916-020-01618-2] [Medline: 32691249]

52. Martin G, Koizia L, Kooner A, Cafferkey J, Ross C, Purkayastha S, PanSurg Collaborative. Use of the HoloLens 2 mixed reality headset for protecting health care workers during the COVID-19 pandemic: prospective, observational evaluation. J Med Internet Res 2020 Aug 14;22(8):e21486 [FREE Full text] [doi: 10.2196/21486] [Medline: 32730222]

53. Couperus K, Young S, Walsh R, Kang C, Skinner C, Essendrop R, et al. Immersive virtual reality medical simulation: autonomous trauma training simulator. Cureus 2020 May 11;12(5):e8062 [FREE Full text] [doi: 10.7759/cureus.8062] [Medline: 32542120]

54. Tamplin J, Loveridge B, Clarke K, Li Y, J Berlowitz D. Development and feasibility testing of an online virtual reality platform for delivering therapeutic group singing interventions for people living with spinal cord injury. J Telemed Telecare 2020 Jul;26(6):365-375. [doi: 10.1177/1357633X19828463] [Medline: 30823854]

55. Pedram S, Palmisano S, Perez P, Mursic R, Farrelly M. Examining the potential of virtual reality to deliver remote rehabilitation. Comput Hum Behav 2020 Apr;105:106223. [doi: 10.1016/j.chb.2019.106223]

56. Matsangidou M, Otkhmezuri B, Ang CS, Avraamides M, Riva G, Gaggioli A, et al. "Now I can see me" designing a multi-user virtual reality remote psychotherapy for body weight and shape concerns. Hum Comput Interact 2020 Oct 16:1-27. [doi: 10.1080/07370024.2020.1788945]

57. Domestic travel during COVID-19. Centers for Disease Control and Prevention. 2021. URL: https://www.cdc.gov/coronavirus/ 2019-ncov/travelers/travel-during-covid19.html [accessed 2021-02-19]

58. Hu S, Chen P. Who left riding transit? Examining socioeconomic disparities in the impact of COVID-19 on ridership. Transport Res D 2021 Jan;90:102654. [doi: 10.1016/j.trd.2020.102654]

59. Liu L, Miller HJ, Scheff J. The impacts of COVID-19 pandemic on public transit demand in the United States. PLoS One 2020;15(11):e0242476 [FREE Full text] [doi: 10.1371/journal.pone.0242476] [Medline: $\underline{33206721]}$ 
60. Hirko KA, Kerver JM, Ford S, Szafranski C, Beckett J, Kitchen C, et al. Telehealth in response to the COVID-19 pandemic: Implications for rural health disparities. J Am Med Inform Assoc 2020 Nov 01;27(11):1816-1818 [FREE Full text] [doi: 10.1093/jamia/ocaa156] [Medline: 32589735]

61. Usher K, Bhullar N, Jackson D. Life in the pandemic: social isolation and mental health. J Clin Nurs 2020 Aug;29(15-16):2756-2757. [doi: 10.1111/jocn.15290] [Medline: 32250493]

62. Jung T, Moorhouse N, Shi X, Amin MF. A virtual reality-supported intervention for pulmonary rehabilitation of patients with chronic obstructive pulmonary disease: mixed methods study. J Med Internet Res 2020 Jul 07;22(7):e14178 [FREE Full text] [doi: $\underline{10.2196 / 14178]}$ [Medline: $\underline{32673224]}$

63. Cai S, Wei X, Su E, Wu W, Zheng H, Xie L. Online compensation detecting for real-time reduction of compensatory motions during reaching: a pilot study with stroke survivors. J Neuroeng Rehabil 2020 Apr 28;17(1):58 [FREE Full text] [doi: 10.1186/s12984-020-00687-1] [Medline: 32345335]

64. Riva G, Mantovani F, Wiederhold BK. Positive technology and COVID-19. Cyberpsychol Behav Soc Netw 2020 Sep;23(9):581-587. [doi: 10.1089/cyber.2020.29194.gri] [Medline: 32833511]

65. Wong RSM, Ho FKW, Tung KTS, Fu K, Ip P. Effect of Pokémon Go on self-harm using population-based interrupted time-series analysis: quasi-experimental study. JMIR Serious Games 2020 Jun 12;8(2):e17112 [FREE Full text] [doi: 10.2196/17112] [Medline: 32530429]

66. Ellis LA, Lee MD, Ijaz K, Smith J, Braithwaite J, Yin K. COVID-19 as 'game changer' for the physical activity and mental well-being of augmented reality game players during the pandemic: mixed methods survey study. J Med Internet Res 2020 Dec 22;22(12):e25117 [FREE Full text] [doi: 10.2196/25117] [Medline: 33284781]

67. Laato S, Laine T, Islam A. Location-Based Games and the COVID-19 Pandemic: An Analysis of Responses from Game Developers and Players. Multimod Technol Interact 2020 Jun 17;4(2):29 [FREE Full text] [doi: 10.3390/mti4020029]

68. Laato S, Islam AN, Laine TH. Did location-based games motivate players to socialize during COVID-19? Telematics Informatics 2020 Nov;54:101458. [doi: 10.1016/j.tele.2020.101458]

69. Baranowski T, Lyons EJ. Scoping review of Pokémon Go: comprehensive assessment of augmented reality for physical activity change. Games Health J 2020 Apr;9(2):71-84 [FREE Full text] [doi: 10.1089/g4h.2019.0034] [Medline: 31386564]

70. Racine N, Hartwick C, Collin-Vézina D, Madigan S. Telemental health for child trauma treatment during and post-COVID-19: Limitations and considerations. Child Abuse Negl 2020 Dec;110(Pt 2):104698 [FREE Full text] [doi:

10.1016/j.chiabu.2020.104698] [Medline: 32839022]

71. Sultana A, Sharma R, Hossain M, Bhattacharya S, Purohit N. Burnout among healthcare providers during COVID-19: Challenges and evidence-based interventions. Indian J Med Ethics 2020;5(4):1-6. [doi: 10.20529/IJME.2020.73] [Medline: 34018959]

72. Sasangohar F, Jones SL, Masud FN, Vahidy FS, Kash BA. Provider burnout and fatigue during the COVID-19 pandemic: lessons learned from a high-volume intensive care unit. Anesth Analg 2020 Jul;131(1):106-111 [FREE Full text] [doi: 10.1213/ANE.0000000000004866] [Medline: 32282389]

73. Tan BY, Kanneganti A, Lim LJ, Tan M, Chua YX, Tan L, et al. Burnout and associated factors among health care workers in Singapore during the COVID-19 pandemic. J Am Med Dir Assoc 2020 Dec;21(12):1751-1758 [FREE Full text] [doi: 10.1016/j.jamda.2020.09.035] [Medline: 33256955]

74. Mutambudzi M, Niedwiedz C, Macdonald EB, Leyland A, Mair F, Anderson J, et al. Occupation and risk of severe COVID-19: prospective cohort study of 120075 UK Biobank participants. Occup Environ Med 2020 Dec 09:oemed-2020-106731. [doi: 10.1136/oemed-2020-106731] [Medline: 33298533]

75. Our key findings about US healthcare worker deaths in the pandemic's first year. The Guardian. 2020 Dec 22. URL: http:/ /www.theguardian.com/us-news/ng-interactive/2020/dec/22/lost-on-the-frontline-our-findings-to-date [accessed 2021-03-11]

76. Joshi G, Sharma G. Burnout: A risk factor amongst mental health professionals during COVID-19. Asian J Psychiatr 2020 Dec;54:102300 [FREE Full text] [doi: 10.1016/j.ajp.2020.102300] [Medline: 32683251]

77. Aydin Sayilan A, Kulakaç N, Uzun S. Burnout levels and sleep quality of COVID-19 heroes. Perspect Psychiatr Care 2020 Nov 04:online ahead of print. [doi: 10.1111/ppc.12678] [Medline: 33145787]

78. Magill E, Siegel Z, Pike KM. The mental health of frontline health care providers during pandemics: a rapid review of the literature. Psychiatr Serv 2020 Dec 01;71(12):1260-1269. [doi: 10.1176/appi.ps.202000274] [Medline: 33019857]

79. Bradley M, Chahar P. Burnout of healthcare providers during COVID-19. Cleve Clin J Med 2020 Jul 09:online ahead of print [FREE Full text] [doi: 10.3949/ccjm.87a.ccc051] [Medline: 32606049]

80. Mehta S, Machado F, Kwizera A, Papazian L, Moss M, Azoulay, et al. COVID-19: a heavy toll on health-care workers. Lancet Respir Med 2021 Mar;9(3):226-228 [FREE Full text] [doi: 10.1016/S2213-2600(21)00068-0] [Medline: 33556317]

81. Muller AE, Hafstad EV, Himmels JPW, Smedslund G, Flottorp S, Stensland, et al. The mental health impact of the covid-19 pandemic on healthcare workers, and interventions to help them: A rapid systematic review. Psychiatry Res 2020 Nov;293:113441 [FREE Full text] [doi: 10.1016/j.psychres.2020.113441] [Medline: 32898840]

82. Moss M, Good VS, Gozal D, Kleinpell R, Sessler CN. A Critical Care Societies Collaborative Statement: Burnout syndrome in critical care health-care professionals. A call for action. Am J Respir Crit Care Med 2016 Jul 01;194(1):106-113. [doi: 10.1164/rccm.201604-0708ST] [Medline: 27367887] 
83. Dharmawardene M, Givens J, Wachholtz A, Makowski S, Tjia J. A systematic review and meta-analysis of meditative interventions for informal caregivers and health professionals. BMJ Support Palliat Care 2016 Jun;6(2):160-169 [FREE Full text] [doi: 10.1136/bmjspcare-2014-000819] [Medline: 25812579]

84. National Academies of Sciences, Engineering, and Medicine. Taking action against clinician burnout: a systems approach to professional well-being. Washington, DC: The National Academies Press; 2019.

85. Eshuis LV, van Gelderen MJ, van Zuiden M, Nijdam MJ, Vermetten E, Olff M, et al. Efficacy of immersive PTSD treatments: A systematic review of virtual and augmented reality exposure therapy and a meta-analysis of virtual reality exposure therapy. J Psychiatr Res 2020 Nov 17:online ahead of print [FREE Full text] [doi: 10.1016/j.jpsychires.2020.11.030] [Medline: 33248674]

86. Sampaio M, Haro MVN, De Sousa B, Melo WV, Hoffman HG. Therapists make the switch to telepsychology to safely continue treating their patients during the COVID-19 pandemic. Virtual reality telepsychology may be next. Front Virtual Real 2021 Jan;1:576421 [FREE Full text] [doi: 10.3389/frvir.2020.576421] [Medline: 33585834]

87. Imperatori C, Dakanalis A, Farina B, Pallavicini F, Colmegna F, Mantovani F, et al. Global storm of stress-related psychopathological symptoms: a brief overview on the usefulness of virtual reality in facing the mental health impact of COVID-19. Cyberpsychol Behav Soc Netw 2020 Nov;23(11):782-788. [doi: 10.1089/cyber.2020.0339] [Medline: 32640852]

88. Pallavicini F, Orena E, di Santo S, Greci L, Caragnano C, Ranieri P, et al. MIND-VR: design and evaluation protocol of a virtual reality psychoeducational experience on stress and anxiety for the psychological support of healthcare workers involved in the COVID-19 pandemic. Front Virt Real 2021 Feb 2;2:online ahead of print. [doi: 10.3389/frvir.2021.620225]

89. Vlake JH, van Bommel J, Hellemons ME, Wils E, Gommers D, van Genderen ME. Intensive care unit-specific virtual reality for psychological recovery after ICU treatment for COVID-19; a brief case report. Front Med 2020;7:629086. [doi: 10.3389/fmed.2020.629086] [Medline: 33614677]

90. Held P, Klassen BJ, Coleman JA, Thompson K, Rydberg TS, Van Horn R. Delivering intensive PTSD treatment virtually: the development of a 2-week intensive cognitive processing therapy-based program in response to COVID-19. Cogn Behav Pract 2020 Oct:online ahead of print. [doi: 10.1016/j.cbpra.2020.09.002]

91. Seabrook E, Kelly R, Foley F, Theiler S, Thomas N, Wadley G, et al. Understanding how virtual reality can support mindfulness practice: mixed methods study. J Med Internet Res 2020 Mar 18;22(3):e16106 [FREE Full text] [doi: 10.2196/16106] [Medline: 32186519 ]

92. Kruse FM, Jeurissen PPT. For-profit hospitals out of business? Financial sustainability during the COVID-19 epidemic emergency response. Int J Health Policy Manag 2020 Oct 01;9(10):423-428 [FREE Full text] [doi: 10.34172/ijhpm.2020.67] [Medline: $\underline{32610731]}$

93. Slonim AD, See H, Slonim S. Challenges confronting rural hospitals accentuated during COVID-19. J Biomed Res 2020 Sep 21;34(6):397-409. [doi: 10.7555/JBR.34.20200112] [Medline: $\underline{33243939]}$

94. Webb Hooper M, Nápoles AM, Pérez-Stable EJ. COVID-19 and racial/ethnic disparities. JAMA 2020 Jun 23;323(24):2466-2467. [doi: 10.1001/jama.2020.8598] [Medline: 32391864]

95. Rose S. Medical student education in the time of COVID-19. JAMA 2020 Jun 02;323(21):2131-2132. [doi: 10.1001/jama.2020.5227] [Medline: $\underline{32232420]}$

96. Theoret C, Ming X. Our education, our concerns: The impact on medical student education of COVID-19. Med Educ 2020 Jul;54(7):591-592 [FREE Full text] [doi: 10.1111/medu.14181] [Medline: 32310318]

97. Cerqueira-Silva T, Carreiro R, Nunes V, Passos L, Canedo BF, Andrade S, et al. Bridging learning in medicine and citizenship during the COVID-19 pandemic: a telehealth-based case study. JMIR Public Health Surveill 2021 Mar 04;7(3):e24795 [FREE Full text] [doi: 10.2196/24795] [Medline: $\underline{33630746]}$

98. Bernard J, Kwong M. Federal and state policies on telehealth reimbursement. In: Latifi R, Doarn CD, Merrell RC, editors. Telemedicine, telehealth and telepresence. Switzerland: Springer International Publishing; 2021:115-127.

99. Glegg SMN, Levac DE. Barriers, facilitators and interventions to support virtual reality implementation in rehabilitation: a scoping review. PM R 2018 Nov;10(11):1237-1251 [FREE Full text] [doi: 10.1016/j.pmrj.2018.07.004] [Medline: 30503231]

100. Kleykamp B, Guille C, Barth K, McClure E. Substance use disorders and COVID-19: the role of telehealth in treatment and research. J Soc Work Pract Addict 2020 Aug 25;20(3):248-253. [doi: 10.1080/1533256x.2020.1793064]

101. Kalron A, Achiron A, Pau M, Cocco E. The effect of a telerehabilitation virtual reality intervention on functional upper limb activities in people with multiple sclerosis: a study protocol for the TEAMS pilot randomized controlled trial. Trials 2020 Aug 12;21(1):713 [FREE Full text] [doi: 10.1186/s13063-020-04650-2] [Medline: 32787896]

102. Goldenhersch E, Thrul J, Ungaretti J, Rosencovich N, Waitman C, Ceberio MR. Virtual reality smartphone-based intervention for smoking cessation: pilot randomized controlled trial on initial clinical efficacy and adherence. J Med Internet Res 2020 Jul 29;22(7):e17571 [FREE Full text] [doi: 10.2196/17571] [Medline: 32723722]

103. Singh RP, Javaid M, Kataria R, Tyagi M, Haleem A, Suman R. Significant applications of virtual reality for COVID-19 pandemic. Diabetes Metab Syndr 2020;14(4):661-664 [FREE Full text] [doi: 10.1016/j.dsx.2020.05.011] [Medline: 32438329]

104. Tabatabai S. COVID-19 impact and virtual medical education. J Adv Med Educ Prof 2020 Jul;8(3):140-143 [FREE Full text] [doi: $\underline{10.30476 / j a m p .2020 .86070 .1213}$ ] [Medline: $\underline{\text { 32802908] }}$ 
105. Goh P, Sandars J. A vision of the use of technology in medical education after the COVID-19 pandemic. MedEdPublish 2020;9(1):1-8. [doi: 10.15694/mep.2020.000049.1]

106. Remtulla R. The present and future applications of technology in adapting medical education amidst the COVID-19 pandemic. JMIR Med Educ 2020 Jul 17;6(2):e20190 [FREE Full text] [doi: 10.2196/20190] [Medline: 32634107]

107. De Ponti R, Marazzato J, Maresca AM, Rovera F, Carcano G, Ferrario MM. Pre-graduation medical training including virtual reality during COVID-19 pandemic: a report on students' perception. BMC Med Educ 2020 Sep 25;20(1):332 [FREE Full text] [doi: 10.1186/s12909-020-02245-8] [Medline: 32977781]

108. Miner H, Fatehi A, Ring D, Reichenberg JS. Clinician telemedicine perceptions during the COVID-19 pandemic. Telemed J E Health 2021 May;27(5):508-512. [doi: 10.1089/tmj.2020.0295] [Medline: 32946364$]$

109. Guido-Estrada N, Crawford J. Embracing telemedicine: the silver lining of a pandemic. Pediatr Neurol 2020 Dec;113:13-14 [FREE Full text] [doi: 10.1016/j.pediatrneurol.2020.08.017] [Medline: 32979652]

110. Pierce BS, Perrin PB, Tyler CM, McKee GB, Watson JD. The COVID-19 telepsychology revolution: A national study of pandemic-based changes in U.S. mental health care delivery. Am Psychol 2021 Jan;76(1):14-25. [doi: 10.1037/amp0000722] [Medline: $\underline{\text { 32816503] }}$

111. Slightam C, Gregory AJ, Hu J, Jacobs J, Gurmessa T, Kimerling R, et al. Patient perceptions of video visits using veterans affairs telehealth tablets: survey study. J Med Internet Res 2020 Apr 15;22(4):e15682 [FREE Full text] [doi: 10.2196/15682] [Medline: 32293573]

112. Ebbert JO, Ramar P, Tulledge-Scheitel SM, Njeru JW, Rosedahl JK, Roellinger D, et al. Patient preferences for telehealth services in a large multispecialty practice. J Telemed Telecare 2021 Jan 18:1357633X20980302. [doi: 10.1177/1357633X20980302] [Medline: $\underline{33461397]}$

113. Reichenbacher T. Telemental health. J Telemed Telecare 2013 Oct 17;19(6):360-361. [doi: 10.1177/1357633x13503430]

114. Sammons MT. Effects of a pandemic on psychologists and the public. J Health Serv Psychol 2020 Nov 08:1-3 [FREE Full text] [doi: 10.1007/s42843-020-00023-0] [Medline: 33196053]

115. Sammons MT, VandenBos GR, Martin JN. Psychological practice and the COVID-19 crisis: a rapid response survey. J Health Serv Psychol 2020 May 08:1-7 [FREE Full text] [doi: 10.1007/s42843-020-00013-2] [Medline: 32395720]

116. Barkai G, Gadot M, Amir H, Menashe M, Shvimer-Rothschild L, Zimlichman E. Patient and clinician experience with a rapidly implemented large-scale video consultation program during COVID-19. Int J Qual Health Care 2021 Feb 20;33(1):mzaa165 [FREE Full text] [doi: 10.1093/intqhc/mzaa165] [Medline: 33313891]

117. Tönnies J, Hartmann M, Wensing M, Szecsenyi J, Peters-Klimm F, Brinster R, et al. Mental health specialist video consultations versus treatment-as-usual for patients with depression or anxiety disorders in primary care: randomized controlled feasibility trial. JMIR Ment Health 2021 Mar 12;8(3):e22569 [FREE Full text] [doi: 10.2196/22569] [Medline: $\underline{33709931]}$

118. Sherer M, Evans CC, Leverenz J, Stouter J, Irby JW, Lee JE, et al. Therapeutic alliance in post-acute brain injury rehabilitation: predictors of strength of alliance and impact of alliance on outcome. Brain Inj 2007 Jun;21(7):663-672. [doi: 10.1080/02699050701481589] [Medline: 17653940 ]

119. Sturgiss EA, Sargent GM, Haesler E, Rieger E, Douglas K. Therapeutic alliance and obesity management in primary care - a cross-sectional pilot using the Working Alliance Inventory. Clin Obes 2016 Dec;6(6):376-379. [doi: 10.1111/cob.12167] [Medline: 27863074]

120. Baier AL, Kline AC, Feeny NC. Therapeutic alliance as a mediator of change: A systematic review and evaluation of research. Clin Psychol Rev 2020 Dec;82:101921. [doi: 10.1016/j.cpr.2020.101921] [Medline: 33069096]

121. Bordin ES. The generalizability of the psychoanalytic concept of the working alliance. Psychother Theor Res Pract 1979;16(3):252-260. [doi: 10.1037/h0085885]

122. Menendez ME, Moverman MA, Puzzitiello RN, Pagani NR, Ring D. The telehealth paradox in the neediest patients. J Natl Med Assoc 2021 Jun;113(3):351-352 [FREE Full text] [doi: 10.1016/j.jnma.2020.09.144] [Medline: 33092857]

123. Holtz BE. Patients perceptions of telemedicine visits before and after the coronavirus disease 2019 pandemic. Telemed $\mathrm{J}$ E Health 2021 Jan;27(1):107-112. [doi: 10.1089/tmj.2020.0168] [Medline: 32614689]

124. Shachak A, Alkureishi MA. Virtual care: a 'Zoombie' apocalypse? J Am Med Inform Assoc 2020 Nov 01;27(11):1813-1815 [FREE Full text] [doi: 10.1093/jamia/ocaa185] [Medline: $\underline{\text { 32940711] }}$

125. Wiederhold BK. Connecting through technology during the coronavirus disease 2019 pandemic: avoiding "Zoom fatigue". Cyberpsychol Behav Soc Netw 2020 Jul;23(7):437-438. [doi: 10.1089/cyber.2020.29188.bkw] [Medline: $\underline{32551981]}$

126. Ackerman SJ, Hilsenroth MJ. A review of therapist characteristics and techniques negatively impacting the therapeutic alliance. Psychother Theor Res Pract Train 2001;38(2):171-185. [doi: 10.1037/0033-3204.38.2.171]

127. Cameron SK, Rodgers J, Dagnan D. The relationship between the therapeutic alliance and clinical outcomes in cognitive behaviour therapy for adults with depression: A meta-analytic review. Clin Psychol Psychother 2018 May;25(3):446-456. [doi: 10.1002/cpp.2180] [Medline: 29484770]

128. Totura CMW, Fields SA, Karver MS. The role of the therapeutic relationship in psychopharmacological treatment outcomes: a meta-analytic review. Psychiatr Serv 2018 Jan 01;69(1):41-47. [doi: 10.1176/appi.ps.201700114] [Medline: 28945182]

129. Flückiger C, Del Re AC, Wampold BE, Horvath AO. The alliance in adult psychotherapy: A meta-analytic synthesis. Psychotherapy 2018 Dec;55(4):316-340. [doi: 10.1037/pst0000172] [Medline: 29792475] 
130. Saiyed S, Nguyen A, Singh R. Physician perspective and key satisfaction indicators with rapid telehealth adoption during the coronavirus disease 2019 pandemic. Telemed J E Health 2021 Jan 29:online ahead of print. [doi: 10.1089/tmj.2020.0492] [Medline: $\underline{33513045]}$

131. Morris ME. Enhancing relationships through technology: directions in parenting, caregiving, romantic partnerships, and clinical practice. Dialogues Clin Neurosci 2020 Jun;22(2):151-160 [FREE Full text] [doi: 10.31887/DCNS.2020.22.2/mmorris] [Medline: 32699515]

132. Mantovani E, Zucchella C, Bottiroli S, Federico A, Giugno R, Sandrini G, et al. Telemedicine and virtual reality for cognitive rehabilitation: a roadmap for the COVID-19 pandemic. Front Neurol 2020;11:926. [doi: 10.3389/fneur.2020.00926] [Medline: 33041963]

133. Riva G, Morganti F, Villamira M. Immersive virtual telepresence: virtual reality meets eHealth. Stud Health Technol Inform 2004;99:255-262. [Medline: 15295155]

134. Miloff A, Carlbring P, Hamilton W, Andersson G, Reuterskiöld L, Lindner P. Measuring alliance toward embodied virtual therapists in the era of automated treatments with the Virtual Therapist Alliance Scale (VTAS): development and psychometric evaluation. J Med Internet Res 2020 Mar 24;22(3):e16660 [FREE Full text] [doi: 10.2196/16660] [Medline: $\underline{\text { 32207690] }}$

135. Oh CS, Bailenson JN, Welch GF. A systematic review of social presence: definition, antecedents, and implications. Front Robot AI 2018;5:114. [doi: 10.3389/frobt.2018.00114] [Medline: 33500993]

136. Heim E, Rötger A, Lorenz N, Maercker A. Working alliance with an avatar: How far can we go with internet interventions? Internet Interv 2018 Mar;11:41-46 [FREE Full text] [doi: 10.1016/j.invent.2018.01.005] [Medline: 30135758]

137. Kreps GL, Neuhauser L. Artificial intelligence and immediacy: designing health communication to personally engage consumers and providers. Patient Educ Couns 2013 Aug;92(2):205-210. [doi: 10.1016/j.pec.2013.04.014] [Medline: 23683341]

138. Pfandler M, Lazarovici M, Stefan P, Wucherer P, Weigl M. Virtual reality-based simulators for spine surgery: a systematic review. Spine J 2017 Sep;17(9):1352-1363. [doi: 10.1016/j.spinee.2017.05.016] [Medline: 28571789]

139. Hilty DM, Alverson DC, Alpert JE, Tong L, Sagduyu K, Boland RJ, et al. Virtual reality, telemedicine, web and data processing innovations in medical and psychiatric education and clinical care. Acad Psychiatry 2006;30(6):528-533. [doi: 10.1176/appi.ap.30.6.528] [Medline: 17139025$]$

140. Verhey JT, Haglin JM, Verhey EM, Hartigan DE. Virtual, augmented, and mixed reality applications in orthopedic surgery. Int J Med Robot 2020 Apr;16(2):e2067. [doi: 10.1002/rcs.2067] [Medline: 31867864]

141. Barrie M, Socha JJ, Mansour L, Patterson ES. Mixed reality in medical education: a narrative literature review. 2019 Sep 15 Presented at: International Symposium on Human Factors and Ergonomics in Health Care; March 24-27, 2019; Chicago, IL p. 28-32. [doi: 10.1177/2327857919081006]

142. Bracq M, Michinov E, Jannin P. Virtual reality simulation in nontechnical skills training for healthcare professionals: a systematic review. Simul Healthc 2019 Jun;14(3):188-194. [doi: 10.1097/SIH.0000000000000347] [Medline: 30601464]

143. Kyaw BM, Saxena N, Posadzki P, Vseteckova J, Nikolaou CK, George PP, et al. Virtual reality for health professions education: systematic review and meta-analysis by the Digital Health Education Collaboration. J Med Internet Res 2019 Jan 22;21(1):e12959 [FREE Full text] [doi: 10.2196/12959] [Medline: 30668519]

144. Khan R, Plahouras J, Johnston BC, Scaffidi MA, Grover SC, Walsh CM. Virtual reality simulation training in endoscopy: a Cochrane review and meta-analysis. Endoscopy 2019 Jul;51(7):653-664. [doi: 10.1055/a-0894-4400] [Medline: 31071757]

145. Piot M, Dechartres A, Attoe C, Jollant F, Lemogne C, Layat Burn C, et al. Simulation in psychiatry for medical doctors: A systematic review and meta-analysis. Med Educ 2020 Aug;54(8):696-708. [doi: 10.1111/medu.14166] [Medline: 32242966]

146. Viglialoro R, Condino S, Turini G, Carbone M, Ferrari V, Gesi M. Augmented reality, mixed reality, and hybrid approach in healthcare simulation: a systematic review. Appl Sci 2021 Mar 06;11(5):2338. [doi: 10.3390/app11052338]

147. Reason J. Understanding adverse events: human factors. Qual Health Care 1995 Jun;4(2):80-89 [FREE Full text] [doi: 10.1136/qshc.4.2.80] [Medline: 10151618 ]

148. Donchin Y, Seagull FJ. The hostile environment of the intensive care unit. Curr Opin Crit Care 2002 Aug;8(4):316-320. [doi: 10.1097/00075198-200208000-00008] [Medline: 12386492]

149. Morita PP, Cafazzo JA. Challenges and paradoxes of human factors in health technology design. JMIR Hum Factors 2016 Mar 01;3(1):e11 [FREE Full text] [doi: 10.2196/humanfactors.4653] [Medline: 27025862]

150. Harte R, Glynn L, Rodríguez-Molinero A, Baker PM, Scharf T, Quinlan LR, et al. A human-centered design methodology to enhance the usability, human factors, and user experience of connected health systems: a three-phase methodology. JMIR Hum Factors 2017 Mar 16;4(1):e8 [FREE Full text] [doi: 10.2196/humanfactors.5443] [Medline: 28302594]

151. Higginbotham G. Virtual connections: improving global neurosurgery through immersive technologies. Front Surg 2021;8:629963. [doi: 10.3389/fsurg.2021.629963] [Medline: 33681283]

152. Edström E, Burström G, Nachabe R, Gerdhem P, Elmi Terander A. A novel augmented-reality-based surgical navigation system for spine surgery in a hybrid operating room: design, workflow, and clinical applications. Oper Neurosurg 2020 May 01;18(5):496-502. [doi: 10.1093/ons/opz236] [Medline: $\underline{31504859}$ ]

153. Kim SK, Lee Y, Yoon H, Choi J. Adaptation of extended reality smart glasses for core nursing skill training among undergraduate nursing students: usability and feasibility study. J Med Internet Res 2021 Mar 02;23(3):e24313 [FREE Full text] [doi: 10.2196/24313] [Medline: $\underline{\text { 33650975] }}$ 
154. Persky S. A virtual home for the virtual clinical trial. J Med Internet Res 2020 Jan 03;22(1):e15582 [FREE Full text] [doi: 10.2196/15582] [Medline: 31899455$]$

155. Horing B, Newsome ND, Enck P, Babu SV, Muth ER. A virtual experimenter to increase standardization for the investigation of placebo effects. BMC Med Res Methodol 2016 Jul 18;16:84 [FREE Full text] [doi: 10.1186/s12874-016-0185-4] [Medline: $\underline{27430476]}$

156. Jimenez YA, Cumming S, Wang W, Stuart K, Thwaites DI, Lewis SJ. Patient education using virtual reality increases knowledge and positive experience for breast cancer patients undergoing radiation therapy. Support Care Cancer 2018 Aug;26(8):2879-2888. [doi: 10.1007/s00520-018-4114-4] [Medline: 29536200]

157. Pandrangi VC, Gaston B, Appelbaum NP, Albuquerque FC, Levy MM, Larson RA. The application of virtual reality in patient education. Ann Vasc Surg 2019 Aug;59:184-189. [doi: 10.1016/j.avsg.2019.01.015] [Medline: 31009725]

158. Perin A, Galbiati TF, Ayadi R, Gambatesa E, Orena EF, Riker NI, et al. Informed consent through 3D virtual reality: a randomized clinical trial. Acta Neurochir 2021 Feb;163(2):301-308. [doi: 10.1007/s00701-020-04303-y] [Medline: 32242272]

159. Senbekov M, Saliev T, Bukeyeva Z, Almabayeva A, Zhanaliyeva M, Aitenova N, et al. The recent progress and applications of digital technologies in healthcare: a review. Int J Telemed Appl 2020;2020:8830200. [doi: 10.1155/2020/8830200] [Medline: $\underline{33343657]}$

160. Bravo P, Edwards A, Barr PJ, Scholl I, Elwyn G, McAllister M, Cochrane Healthcare Quality Research Group, Cardiff University. Conceptualising patient empowerment: a mixed methods study. BMC Health Serv Res 2015 Jul 01;15:252 [FREE Full text] [doi: 10.1186/s12913-015-0907-z] [Medline: 26126998]

161. Earnshaw VA, Quinn DM. The impact of stigma in healthcare on people living with chronic illnesses. J Health Psychol 2012 Mar;17(2):157-168. [doi: 10.1177/1359105311414952] [Medline: 21799078]

162. Cook J, Salter A, Stadler G. Identity concealment and chronic illness: a strategic choice. J Social Issues 2017 Jun 19;73(2):359-378. [doi: 10.1111/josi.12221]

163. Mansfield A, Addis M, Mahalik J. "Why won't he go to the doctor?": The psychology of men's help seeking. Int J Men Health 2003 May 1;2(2):93-109. [doi: 10.3149/jmh.0202.93]

164. Gast J, Peak T. "It used to be that if it weren't broken and bleeding profusely, I would never go to the doctor": men, masculinity, and health. Am J Mens Health 2011 Jul;5(4):318-331 [FREE Full text] [doi: 10.1177/1557988310377926] [Medline: 20798142]

165. Himmelstein MS, Sanchez DT. Masculinity in the doctor's office: Masculinity, gendered doctor preference and doctor-patient communication. Prev Med 2016 Mar;84:34-40. [doi: 10.1016/j.ypmed.2015.12.008] [Medline: 26724519]

166. Whitehead J, Shaver J, Stephenson R. Outness, stigma, and primary health care utilization among rural LGBT populations. PLoS One 2016;11(1):e0146139 [FREE Full text] [doi: 10.1371/journal.pone.0146139] [Medline: 26731405]

167. Layland EK, Carter JA, Perry NS, Cienfuegos-Szalay J, Nelson KM, Bonner CP, et al. A systematic review of stigma in sexual and gender minority health interventions. Transl Behav Med 2020 Oct 12;10(5):1200-1210. [doi: 10.1093/tbm/ibz200] [Medline: 33044540]

168. Reas DL. Public and healthcare professionals' knowledge and attitudes toward binge eating disorder: a narrative review. Nutrients 2017 Nov 21;9(11):1267 [FREE Full text] [doi: 10.3390/nu9111267] [Medline: 29160843]

169. Phelan SM, Burgess DJ, Yeazel MW, Hellerstedt WL, Griffin JM, van Ryn M. Impact of weight bias and stigma on quality of care and outcomes for patients with obesity. Obes Rev 2015 Apr;16(4):319-326 [FREE Full text] [doi: 10.1111/obr.12266] [Medline: 25752756]

170. Frank JW, Wang EA, Nunez-Smith M, Lee H, Comfort M. Discrimination based on criminal record and healthcare utilization among men recently released from prison: a descriptive study. Health Justice 2014 Mar 25;2:6. [doi: 10.1186/2194-7899-2-6] [Medline: 25642407]

171. Dandachi D, Dang BN, Lucari B, Teti M, Giordano TP. Exploring the attitude of patients with HIV about using telehealth for HIV care. AIDS Patient Care STDS 2020 Apr;34(4):166-172. [doi: 10.1089/apc.2019.0261] [Medline: 32324481]

172. Oesterle TS, Kolla B, Risma CJ, Breitinger SA, Rakocevic DB, Loukianova LL, et al. Substance use disorders and telehealth in the COVID-19 pandemic era: a new outlook. Mayo Clin Proc 2020 Dec;95(12):2709-2718 [FREE Full text] [doi: 10.1016/j.mayocp.2020.10.011] [Medline: 33276843]

173. Craig SL, Iacono G, Pascoe R, Austin A. Adapting clinical skills to telehealth: applications of affirmative cognitive-behavioral therapy with LGBTQ+ youth. Clin Soc Work J 2021 Mar 02:1-13 [FREE Full text] [doi: 10.1007/s10615-021-00796-x] [Medline: $\underline{3678921]}$

174. Kim C, Jung M, Kim S, Kim K. Controlling the sense of embodiment for virtual avatar applications: methods and empirical study. JMIR Serious Games 2020 Sep 22;8(3):e21879 [FREE Full text] [doi: 10.2196/21879] [Medline: 32960174]

175. O'Connor S. Virtual reality and avatars in health care. Clin Nurs Res 2019 Jun;28(5):523-528. [doi: 10.1177/1054773819845824] [Medline: 31064283 ]

176. Chua IS, Jackson V, Kamdar M. Webside manner during the COVID-19 pandemic: maintaining human connection during virtual visits. J Palliat Med 2020 Nov;23(11):1507-1509. [doi: 10.1089/jpm.2020.0298] [Medline: 32525744]

177. Sharma P, Vleugels RA, Nambudiri VE. Augmented reality in dermatology: Are we ready for AR? J Am Acad Dermatol 2019 Nov;81(5):1216-1222. [doi: 10.1016/j.jaad.2019.07.008] [Medline: 31302186] 
178. Obagi ZA, Rundle CW, Dellavalle RP. Widening the scope of virtual reality and augmented reality in dermatology. Dermatol Online J 2020 Jan 15;26(1):13030 [FREE Full text] [Medline: $\underline{\text { 32155022] }}$

179. Fromberger P, Jordan K, Müller JL. Virtual reality applications for diagnosis, risk assessment and therapy of child abusers. Behav Sci Law 2018 Mar;36(2):235-244. [doi: 10.1002/bsl.2332] [Medline: 29520819]

180. Lafortune D, Dion L, Renaud P. Virtual reality and sex therapy: future directions for clinical research. J Sex Marital Ther 2020;46(1):1-17. [doi: 10.1080/0092623X.2019.1623357] [Medline: 31124395]

181. Kendzor DE, Hébert ET. The best of both worlds: Avatar-assisted therapy offers the benefits of therapist-assisted and Internet-based interventions. Am J Drug Alcohol Abuse 2017 Sep;43(5):492-494. [doi: 10.1080/00952990.2017.1318396] [Medline: 28481633]

182. Tabbaa L, Ang C, Siriaraya P, She W, Prigerson H. A reflection on virtual reality design for psychological, cognitive and behavioral interventions: design needs, opportunities and challenges. Int J Hum Comput Interact 2020 Dec 01;37(9):851-866. [doi: 10.1080/10447318.2020.1848161]

183. Schultze U. Embodiment and presence in virtual worlds: a review. J Inf Technol 2010 Dec 1;25(4):434-449. [doi: 10.1057/jit.2010.25]

184. Peek K, Sanson-Fisher R, Mackenzie L, Carey M. Interventions to aid patient adherence to physiotherapist prescribed self-management strategies: a systematic review. Physiotherapy 2016 Jun;102(2):127-135. [doi: 10.1016/j.physio.2015.10.003] [Medline: 26821954]

185. Essery R, Geraghty AWA, Kirby S, Yardley L. Predictors of adherence to home-based physical therapies: a systematic review. Disabil Rehabil 2017 Mar;39(6):519-534. [doi: 10.3109/09638288.2016.1153160] [Medline: 27097761]

186. Argent R, Daly A, Caulfield B. Patient involvement with home-based exercise programs: can connected health interventions influence adherence? JMIR Mhealth Uhealth 2018 Mar 01;6(3):e47 [FREE Full text] [doi: 10.2196/mhealth.8518] [Medline: 29496655]

187. Granqvist A, Takala T, Takatalo J, Hämäläinen P. Exaggeration of avatar flexibility in virtual reality. USA: Association for Computing Machinery; 2018 Presented at: 2018 Annual Symposium on Computer-Human Interaction in Play; October 28-31, 2018; Melbourne, Australia. [doi: 10.1145/3242671.3242694]

188. Ioannou C, Archard P, O'Neill E, Lutteroth C. USA: Association for Computing Machinery; 2019 Presented at: 2019 CHI Conference on Human Factors in Computing Systems; May 4-9, 2019; Glasgow, Scotland. [doi: 10.1145/3290605.3300388]

189. Dellazizzo L, Potvin S, Phraxayavong K, Dumais A. Exploring the benefits of virtual reality-assisted therapy following cognitive-behavioral therapy for auditory hallucinations in patients with treatment-resistant schizophrenia: a proof of concept. J Clin Med 2020 Sep 30;9(10):3169 [FREE Full text] [doi: 10.3390/jcm9103169] [Medline: $\underline{33007909]}$

190. Costa M, Bergen-Cico D, Razza R, Hirshfield L, Wang Q. Perceived restorativeness and meditation depth for virtual reality supported mindfulness interventions. : Cognition, Learning and Games Internet Springer International Publishing; 2020 Presented at: HCI International 2020; July 19-24, 2020; Copenhagen, Denmark p. 176-189. [doi: 10.1007/978-3-030-60128-7_14]

191. Tamplin J, Baker FA, Grocke D, Berlowitz DJ. Thematic analysis of the experience of group music therapy for people with chronic quadriplegia. Top Spinal Cord Inj Rehabil 2014;20(3):236-247 [FREE Full text] [doi: 10.1310/sci2003-236] [Medline: 25484569]

192. Yee N, Bailenson J. The Proteus effect: the effect of transformed self-representation on behavior. Human Comm Res 2007 Jul;33(3):271-290. [doi: 10.1111/j.1468-2958.2007.00299.x]

193. Olayiwola JN, Magaña C, Harmon A, Nair S, Esposito E, Harsh C, et al. Telehealth as a bright spot of the COVID-19 pandemic: recommendations from the virtual frontlines ("Frontweb"). JMIR Public Health Surveill 2020 Jun 25;6(2):e19045 [FREE Full text] [doi: 10.2196/19045] [Medline: $\underline{\text { 32479413] }}$

194. Reeves JJ, Ayers JW, Longhurst CA. Telehealth in the COVID-19 era: a balancing act to avoid harm. J Med Internet Res 2021 Feb 01;23(2):e24785 [FREE Full text] [doi: 10.2196/24785] [Medline: 33477104]

195. Pimentel D, Foxman M, Davis DZ, Markowitz DM. Virtually real, but not quite there: social and economic barriers to meeting virtual reality's true potential for mental health. Front Virtual Real 2021 Feb 17;2:online ahead of print. [doi: 10.3389/frvir.2021.627059]

196. Robertson A. Valve Index review: high-powered VR at a high-end price. The Verge. 2019 Jun 28. URL: https://www. theverge.com/2019/6/28/19102584/valve-index-steamvr-headset-review-shipping-today [accessed 2021-04-15]

197. Patel P, Ivanov D, Bhatt S, Mastorakos G, Birckhead B, Khera N, et al. Low-cost virtual reality headsets reduce perceived pain in healthy adults: a multicenter randomized crossover trial. Games Health J 2020 Apr;9(2):129-136. [doi: 10.1089/g4h.2019.0052] [Medline: 31804853]

198. Pinto S, Quintarelli S, Silani V. New technologies and amyotrophic lateral sclerosis - which step forward rushed by the COVID-19 pandemic? J Neurol Sci 2020 Nov 15;418:117081 [FREE Full text] [doi: 10.1016/j.jns.2020.117081] [Medline: 32882437]

199. Shachar C, Engel J, Elwyn G. Implications for telehealth in a postpandemic future: regulatory and privacy issues. JAMA 2020 Jun 16;323(23):2375-2376. [doi: 10.1001/jama.2020.7943] [Medline: $\underline{32421170]}$ 
200. Lebeck K, Ruth K, Kohno T, Roesner F. Towards security and privacy for multi-user augmented reality: foundations with end users. 2018 Presented at: IEEE Symposium on Security and Privacy; May 21-23, 2018; San Francisco, CA p. $392-408$. [doi: 10.1109/sp.2018.00051]

201. De Guzman JA, Thilakarathna K, Seneviratne A. Security and privacy approaches in mixed reality. ACM Comput Surv 2020 Jan 21;52(6):1-37. [doi: 10.1145/3359626]

202. Oculus for Business Development Guide Internet. Oculus. URL: https://developer.oculus.com/documentation/ofb/ ofb-developer-reference/ [accessed 2021-04-15]

203. Ferreira A, Cruz-Correia R. COVID-19 and cybersecurity: finally, an opportunity to disrupt? JMIRx Med 2021;2(2):e21069 [FREE Full text] [doi: 10.2196/21069] [Medline: $\underline{\text { 34032816] }}$

204. Simms S, Mehta P, Jones CW, Johnston P. A supervisory approach to implementing a pandemic-induced, practice-based change to telehealth. J Family Psychother 2021 Jan 11;31(3-4):141-156. [doi: 10.1080/2692398x.2020.1865768]

205. Gibson N, Arends R, Voss J, Marckstadt S, Nissen MK. Reinforcing telehealth competence through nurse practitioner student clinical experiences. J Nurs Educ 2020 Jul 01;59(7):413-417. [doi: 10.3928/01484834-20200617-12] [Medline: $\underline{32598014]}$

206. Logan DE, Simons LE, Caruso TJ, Gold JI, Greenleaf W, Griffin A, et al. Leveraging virtual reality and augmented reality to combat chronic pain in youth: position paper from the interdisciplinary network on virtual and augmented technologies for pain management. J Med Internet Res 2021 Apr 26;23(4):e25916 [FREE Full text] [doi: 10.2196/25916] [Medline: 33667177]

207. Ligthart S, Meynen G, Biller-Andorno N, Kooijmans T, Kellmeyer P. Is virtually everything possible? The relevance of ethics and human rights for introducing extended reality in forensic psychiatry. AJOB Neurosci 2021 Mar 29:1-14. [doi: 10.1080/21507740.2021.1898489] [Medline: 33780323]

208. Martinez-Martin N, Kreitmair K. Ethical issues for direct-to-consumer digital psychotherapy apps: addressing accountability, data protection, and consent. JMIR Ment Health 2018 Apr 23;5(2):e32 [FREE Full text] [doi: 10.2196/mental.9423] [Medline: 29685865]

209. Sorkin DH, Janio EA, Eikey EV, Schneider M, Davis K, Schueller SM, et al. Rise in use of digital mental health tools and technologies in the United States during the COVID-19 pandemic: survey study. J Med Internet Res 2021 Apr 16;23(4):e26994 [FREE Full text] [doi: 10.2196/26994] [Medline: $\underline{33822737]}$

210. Number of virtual reality (VR) and augmented reality (AR) users in the United States from 2017 to 2022. Statista. 2020. URL: https://www.statista.com/statistics/1017008/united-states-vr-ar-users/ [accessed 2021-04-15]

211. Nanou E. Is virtual reality really the future of everything? MUO. 2021 Mar 20. URL: https://www.makeuseof.com/ virtual-reality-future-of-everything/ [accessed 2021-04-15]

212. Marr B. The 5 Biggest Virtual And Augmented Reality Trends In 2020 Everyone Should Know About. Forbes Magazine. 2020 Jan 24. URL: https://www.forbes.com/sites/bernardmarr/2020/01/24/

the-5-biggest-virtual-and-augmented-reality-trends-in-2020-everyone-should-know-about/?sh=51d47e224a8d [accessed 2021-04-15]

213. Cieślik B, Mazurek J, Rutkowski S, Kiper P, Turolla A, Szczepańska-Gieracha J. Virtual reality in psychiatric disorders: A systematic review of reviews. Complement Ther Med 2020 Aug;52:102480 [FREE Full text] [doi: 10.1016/j.ctim.2020.102480] [Medline: 32951730]

214. Hategan A, Giroux C, Bourgeois JA. Digital technology adoption in psychiatric care: an overview of the contemporary shift from technology to opportunity. J Technol Behav Sci 2019 Mar 7;4(3):171-177. [doi: 10.1007/s41347-019-00086-x]

215. Andrews C, Southworth MK, Silva JNA, Silva JR. Extended reality in medical practice. Curr Treat Options Cardiovasc Med 2019 Mar 30;21(4):18 [ [FREE Full text] [doi: 10.1007/s11936-019-0722-7] [Medline: $\underline{\text { 30929093] }}$

216. Parveau M, Adda M. Toward a user-centric classification scheme for extended reality paradigms. J Ambient Intell Human Comput 2019 Jun 18;11(6):2237-2249. [doi: 10.1007/s12652-019-01352-9]

217. Garrett B, Taverner T, Gromala D, Tao G, Cordingley E, Sun C. Virtual reality clinical research: promises and challenges. JMIR Serious Games 2018 Oct 17;6(4):e10839 [FREE Full text] [doi: 10.2196/10839] [Medline: 30333096]

218. Birckhead B, Khalil C, Liu X, Conovitz S, Rizzo A, Danovitch I, et al. Recommendations for methodology of virtual reality clinical trials in health care by an international working group: iterative study. JMIR Ment Health 2019 Jan 31;6(1):e11973 [FREE Full text] [doi: 10.2196/11973] [Medline: 30702436]

219. Migoya-Borja M, Delgado-Gómez D, Carmona-Camacho R, Porras-Segovia A, López-Moriñigo JD, Sánchez-Alonso M, et al. Feasibility of a virtual reality-based psychoeducational tool (VRight) for depressive patients. Cyberpsychol Behav Soc Netw 2020 Apr;23(4):246-252. [doi: 10.1089/cyber.2019.0497] [Medline: 32207997]

220. Marks SJ, Schick A, Charney JZ, Huang YP, Song SK, Eichenbaum JW, et al. The association of papilledema with syringomyelia: case report. Mt Sinai J Med 1988 Sep;55(4):333-338. [Medline: $\underline{3266306}$ ]

\section{Abbreviations \\ AR: augmented reality \\ CBT: cognitive behavioral therapy}


MR: mixed reality

PPE: personal protective equipment

VR: virtual reality

XR: extended reality

Edited by N Zary; submitted 15.12.20; peer-reviewed by WC Hsu, S Liu, X Shi, Z Ye, G Martin; comments to author 26.01.21; revised version received 07.05.21; accepted 15.06.21; published 26.07.21

Please cite as:

Ong T, Wilczewski H, Paige SR, Soni H, Welch BM, Bunnell BE

Extended Reality for Enhanced Telehealth During and Beyond COVID-19: Viewpoint

JMIR Serious Games 2021;9(3):e26520

URL: https://games.jmir.org/2021/3/e26520

doi: $10.2196 / 26520$

PMID: 34227992

(C)Triton Ong, Hattie Wilczewski, Samantha R Paige, Hiral Soni, Brandon M Welch, Brian E Bunnell. Originally published in JMIR Serious Games (https://games.jmir.org), 26.07.2021. This is an open-access article distributed under the terms of the Creative Commons Attribution License (https://creativecommons.org/licenses/by/4.0/), which permits unrestricted use, distribution, and reproduction in any medium, provided the original work, first published in JMIR Serious Games, is properly cited. The complete bibliographic information, a link to the original publication on https://games.jmir.org, as well as this copyright and license information must be included. 